\title{
Shakespearean Pedagogy and Copious Paradox: How Might we Queer Shakespeare's Work?
}

\author{
Sky Gilbert \\ University of Guelph
}

\begin{abstract}
Despite opposition to 'queering the text' by established Shakespeare critics, this essay sets out to ponder the possibility of teaching Shakespeare in a queer context. The essay begins by examining the social and sexual conditions of the early modern period, making the observation that there were a wide variety of sexualities, moral attitudes, and sexual practices at that time, and that often the early modern moral codes of conduct contradicted each other. It then traces the significance of the rhetorical device of paradox through Lyly and Castiglione, and examines the method of Elizabethan rhetoric, which involved 'copia' (the elaboration of one idea into a variety of ideas through language) and its associated variety of meanings. The essay then turns to the text of Shakespeare's Venus and Adonis, observing that its subject matter-the love of an older woman for a younger man - may have reflected the early modern heterosexual fear of women's sexualityand continues to baffle male critics today. Finally, turning to the poem itself-analyzing it in terms of 'copia' and paradox - the conclusion suggests that perhaps there was a relationship between Shakespeare's use of these rhetorical techniques and the sexuality of his time.
\end{abstract}

Keywords: feminist, queer, rhetoric, early modern, Shakespeare, sexuality

Dr. Sky Gilbert: poet, novelist, actor, playwright, filmmaker, theatre director, and drag queen extraordinaire, former artistic director of Toronto's Buddies in Bad Times Theatre, has had more than 40 plays produced, and written 7 novels, three poetry collections - and a memoir. He has received three Dora Mavor Moore Awards, the Pauline McGibbon Award, The Silver Ticket Award, and the ReLit Award. 'Sky Gilbert Lane' in Toronto is named after him. Guernica Editions recently published Sky's book Small Things. Dr. Gilbert is a Professor at the School of English and Theatre Studies in Guelph specializing in creative writing, sexuality, and Shakespeare.

Email: sky@uoguelph.ca 
Queering the classroom is more than just honouring rainbow signs that proclaim the room a 'safe space.' We must also honour our histories as Lesbian, Gay, Bisexual, and Transgender (LGBT) people. This process is more transparent in the social sciences, where there are, for instance, actual historical facts; confirmed dates and confirmed data, as well as literary, scientific and archeological discoveries. English literature is often a matter of interpretation. And when we study Shakespeare's work, there is a tendency to assume not merely that 'the Bard' himself was heterosexual, but that interpretations related to same-sex desire have been imposed by the interpreters.

\section{Foucault's Approach}

Foucault (1978) says of literary texts in What is an Author?: "From where does it come, who wrote it, when, under what circumstances, or beginning with what design? The meaning ascribed to it and the status or value accorded it depend on the manner we answer these questions" (p. 213). Perhaps no other western author has quite as many assumptions and associations attached to their name as Shakespeare-and many of those assumptions involve his sexuality. This essay suggests how we might 'queer' Shakespeare's work for the classroom through the lens of New Historicism, focusing on Venus and Adonis as an exemplary Early Modern queer poem.

\section{Methodology}

The methodology here is to offer a close reading of Venus and Adonis, observing first that Early Modern sexuality could be characterized as both copious and paradoxical, and that these attributes are mirrored in the rhetorical devices utilized by Shakespeare in his famous poem.

\section{Opposition to Queering the Text}

Stephen-Guy Bray (2002), in his study of Roman pastorals, suggests that:

Consumers of texts, even of the famous classical texts central to Renaissance notions of culture, history and identity, similarly interpret texts as they move through them, according to their own 'interests and desires.' If a famous classical text is a public place open to all who could read Latin, a reading that highlighted its homoeroticism-a reading that might inform a new poem-might turn that place into a space. (p. 7)

And yet the most respected members of the critical establishment are skeptical of those who search for queer 'spaces' in Shakespeare's work. Stanley Wells (general editor of the Oxford and Penguin Shakespeare, and honorary president of the Shakespeare Birthplace Trust) warns us to be wary of interpreting the Bard's work as sexual. He asks us to consider the question: "When...do sexual interpretations proceed from what would once have been considered the dirty minds of the interpreters?" (2004, p. 2).

In Looking for Sex in Shakespeare, Wells also criticizes what he considers wild goose chases in search of sexual subtext. He admits that Shakespeare, the man, if he "did not, in the fullest sense of the word, love a man, he certainly understood the feelings of those who do" (2004, p. 65), nevertheless, he concludes that Shakespeare is somewhat heroic in his heterosexuality, that he "is the greatest celebrant of heterosexual love" (2004, p. 68). Harold Bloom (1999), whose weighty bestselling tome Shakespeare: the Invention of the Human is for many the defining work of 20th Century Shakespearean scholarship, is concerned too about our greatest living writer being placed 
under the gaze of a man who was the most famous of all gay philosophers, saying: "Shakespeare does not fit very well into Foucault's 'archives"' (p. 9). When it comes specifically to foregrounding lesbian sexuality, scholar Dympna Callaghan (past president of the Shakespeare Association of America, and editor of A Feminist Companion to Shakespeare) rules Shakespeare as fundamentally disqualified. She speaks of the situation of women in Shakespeare's Twelfth Night as one in which the unmentionable, but much referenced; vagina hangs like an invisible cloud over a play in which, "femininity is little less than an impossible condition, and female authority a ridiculous one" (2002, p. 43). Under such formidable opposition how might one begin to ferret out Bray's queer 'spaces' in Shakespeare's work?

\section{Definition of the New Historicism}

If we ignore Bloom's advice and press forward with a Foucauldian approach to Shakespeare, we will find ourselves in the New Historicist camp. Stephen Greenblatt (1991) often acknowledges his debt to Foucault's 'archives.' His definition of the New Historicism states that his concern with literary texts:

Has been to reflect upon the historical circumstances of their original production and consumption and to examine the relationship between these circumstances and our own.... The idea is not to find outside the work of art some rock onto which interpretation can be securely claimed, but rather to situate the work in relation to other representational practices operative in the culture at the given moment in both its history and our own. (p. 43)

Greenblatt's scholarship is based on Foucault's (1966) notions of epistemes. Foucault posits that various eras are dominated by overarching fundamental assumptions that change significantly the way we perceive people and their actions. Foucault asserted, quite memorably, in The History of Sexuality, that the notions 'homosexual' and 'heterosexual' did not appear until the late 19th century. Thus, in the Early Modern period, there could have been no homosexuals, only sodomitical acts: "The sodomite had been a temporary aberration; the homosexual was now a species" (1978, p. 43).

\section{Contradictory New Historicist Approaches}

Although there may have been no notion of homosexuality in Shakespeare's time, there were certainly same-sex acts. How were they understood or perceived? Stephen Orgel (1989) and Valerie Traub (2016) offer arguments for certain specific kinds of acknowledgment of same-sex desire in the Early Modern period. Orgel suggests:

What is less often observed is that along with the varieties of conventional romance, romantic and even erotic homosexual relationships also figure from time to time in the literature of the period, in a context that is often - though certainly not invariablypositive, and registers again surprisingly little anxiety about the matter. (p.14)

He goes on to say:

Homosexuality in this culture appears to have been less threatening than hetero-sexuality, and only in part because it had fewer consequences and was easier to desexualize. The reason always given for the prohibition of women from the stage was that their chastity would thereby be compromised, which is understood to mean that they would become 
whores. Behind the outrage of public modesty is a real fear of women's sexuality, and more specifically, of its power to evoke men's sexuality. (p. 17)

And yet Valerie Traub (2016) tells us that during the Early Modern period women's sexuality was written about (mainly by men) with a certain freedom that might shock us even today. She quotes Richard Brome's play The Antipodes (1638) about a young woman whose husband is having difficulties consummating their marriage. The woman confides in a female friend who tells her "A wanton mayd once lay with me, and kiss'd / and clipt and clapt me strangely and she wished / that I had been a man to have got her with childe" (2016, p. 104). Traub also mentions The Choise of Valentines or the Merie Ballad of Nash his Dildo (1592), a work of Elizabethan pornography by Thomas Nashe. The play takes place in a brothel where young ladies educate naive young men about sex. After having sex with the young man, one woman is unsatisfied and pleases herself with a dildo. On the surface at least, this does not sound like a male culture that is afraid of women's desires.

Here is a hint of a sexuality both complex and abundant. How can we compare it to our own? Traub proposes that two opposing approaches to historicism appeared in response to Foucault: continuity and alterity. Continuity refers to those who "emphasize a similarity between past and present concepts of sexual understanding" whereas alterity refers to "those who highlight historical difference" (2016, p. 82).

\section{The Facts of Life in the Early Modern Period}

History provides us with an array of facts about Early Modern life. Joy Lee Gibson (2000) reminds us of many of the realities of London existence at this time. For instance, the population nearly doubled during Elizabeth I's reign. Life was short, and people married soon after their spouses died. "There was really no such thing as childhood" (2000, p. 13) as children were exposed to the most extreme horrors of life from an early age. Six thousand people were executed in public during the Elizabethan period, and these spectacles were enjoyed along with bull-baiting and cockfighting. Probably one of the most revealing facts in terms of sexuality was that people "lived in crowded houses that were unsanitary in the extreme...most houses were small and there was very little privacy" (2000, p. 13). This means that the bedrooms had no doors-as family members had to go through one room to get to another. And, significantly, people went to the bathroom in front of other people. If the environment has anything to do with behaviour, then we must assume people who have no privacy for sex or going to the bathroom would think very differently about their bodily functions than people who live in London today-where privacy is considered a prerequisite for civilized life.

\section{The Facts of Sex in the Early Modern Period}

Valerie Traub (2016) has compiled a list of what scholars now know about Early Modern sex in England. Apparently, sexual contact for adult men and women was considered generally desirable, but sexual control was important to "household order, including the patriarch's self control and governance of women" (p. 139). Sexual matters were "community matters"”, and sexual pleasure was important to "good health and conceiving children" (p. 139) — hence celebrations on a wedding night might involve a communal disrobing of the bride and groom to encourage copulation. As well, there were, "high numbers of unmarried adults" (2016, p. 140). But contradictions also existed, as there was "an official horror of sodomy set against the 
valorization of intimate male friendship (2016, p. 140). Also, there were, "limited options available to women, who nonetheless fashioned idioms to articulate their desires for men and for one another" (2016, p. 140). And there was, "the endurance of a double standard regarding male honour and female reputation, enforced by women as well as men" (2016, p. 140). Surprisingly perhaps there was, "the rise of an indigenous erotica and pornography (2016, p. 140), and perhaps not so surprisingly, "all-too quotidian acts of violence among domestic intimates" (2016, p. 141). And finally, Laura Gowering (as cited by Traub), tells us that people practiced, "a wide repertory of behaviour that avoided pregnancy and alleviated sin" (2016, p. 151). In other words, in a culture which held procreative sex in high esteem, people commonly did anything but that.

The fact is that citizens in Early Modern England engaged in a vast variety of sexual activities, and since sex was considered a good thing for adults to do, sex probably occurred often. There was then a certain variety-let us say 'copiousness' - of sexual activities. But what is really striking about these attitudes and activities is their inconsistency. Widespread moralism accompanied widespread sexual activity. There was condemnation of sodomy along with an encouragement of intimate male friendships, and though women were highly policed, they still discovered ways to satisfy themselves and their partners. This suggests, if not a widespread hypocrisy, then certainly, that there were contradictory ideas and practices. Early Modern sexuality was paradoxical; and rather than being analyzable in terms of modern binaries, these paradoxes were left unresolved. Valerie Traub (2016) confirms this interpretation, cautioning us that a moralistic lens through which we tend to analyze sexuality is not helpful: "None of the bicameral rubrics through which we routinely process Early Modern sex - the licit and the illicit, the homo and the hetero, the queer and the normative, erotic acts and erotic identities-provide us with much analytical purchase" (p. 113).

\section{Sexuality in Venus and Adonis: A Queer Poem?}

Elizabethan sexual activities were many and contradictory, and the usual categories (such as gay, straight, or queer) do not apply. It might make sense to consider the possibility that queer 'spaces' are not to be found in the usual places in Early Modern life. For instance, according to Ben Saunders (2006), "in the Renaissance, the love that dare not speak its name is not homosexuality but rather any love that dares to posit a woman as worthy of a man's complete devotion" (p. 15). Sinfield (2006) speaks of an Early Modern trope in which heterosexual romance meant, for males, "“a fall into impotence of powerlessness, a loss of manly strength, and even of identity" (p. 159). Perhaps a story which privileges a woman's overpowering and all-pervasive passion for a young man may be the place that queers can come closest to finding a 'space' for themselves in Shakespeare.

Shakespeare's Venus and Adonis lies at the centre of the complex and copious contradictions that comprised Elizabethan sexuality. The work has not received the same critical attention as Shakespeare's sonnets or plays. This may be because it is somewhat pornographic even by modern standards. Also, there is the unsettling subject matter: the story concerns an older goddess (Venus) who lusts after a teenage boy (Adonis). But Venus -- after chasing Adonis into the forest-cannot persuade him to have sex with her. The young man escapes and hunts a boar. The boar ultimately gores him. Venus, discovering his dead body, curses all love. 


\section{Elizabethan Pornography?}

Though the poem is pornographic, it is not filled with sexual puns, as many of Shakespeare's comedies are, nor is it as explicit as the pornographic pamphlet that is often referred to as 'Nashe's Dildo.' But there is something even more sexual and compelling about figurative and expressive rhetoric applied to sexual caresses: "Even so she kisses his brow, his cheek, his chin, / And where she ends, she doth anew begin" (Shakespeare, 2002, 178). And Venus entreats him: "I'll be a park, and thou shalt be my deer: / Feed where thou wilt, on mountain, or in dale; /Graze on my lips, and if those hills be dry, / Stray lower, where the pleasant fountains lie" (Shakespeare, 2002, 187). Adonis is described much as a titillating female virgin of the period might be, his skin drifting sensuously between red and white--"Still he is sullen, still he lours and frets, / Twixt crimson shame, and anger ashy pale, / Being red she loves him best, and being white, / Her best is bettered with a more delight" (Shakespeare, 2002, 179).

\section{The Early Modern Male as Sex Object and the Modern Desiring Woman}

In Colin Burrow's edition of the poem, he speaks of the similarities between the way Ovid and Shakespeare were received in the Early Modern period. Speaking of Ovid as a source for Shakespeare's poem, Burrow (2002) says:

Is Adonis lovely as a girl?....Renaissance readers of Ovid responded vigorously to this aspect of his art, which is not anything so reassuringly stable as 'homosexual:' it makes any reader who is committed to reading with his or her sexual desires alive experience sexuality as a dislocating force. (p. 21)

This bewitching and upsetting concoction of a desiring woman and a sexualized young man is perhaps more unsettling than the 'explicit' aspects of Shakespeare's poem-for Early Modern readers and for contemporary ones, as well. Critic, John Klause (1991) seems to take it for granted that Venus is a very difficult character to identify with. In this passage, he bemoans her arrogance and her lusts:

Venus never questions the litany of her passions, never regrets her onslaughts, and never quite attains a self-abnegating respect for the rights and privileges of another. Indeed, in her sour leave-taking after Adonis' death, she may seem extravagantly mean spirited, hardly of a disposition to inspire in an accommodating observer a sympathetic attitude. (p. 101)

Klause's inability to find Venus sympathetic is not necessarily justified by the text. He assumes that readers might not identify with Venus simply because she unequivocally, aggressively, and quite openly desires a beautiful man much younger than herself-so much so that she is bitter when her advances towards him are ignored. One must ask-if the poem were about the bitterness of an aggressive male suitor whose advances to a young woman were ignored, would critics label the hero unsympathetic? Probably not, as Western literature has traditionally mined this fertile subject matter, rarely criticizing, ethically, the choices of an older male suitor.

The present day hypocrisy concerning this double standard (older males are allowed to be attracted to younger women but not the other way around) is rampant. The movie P.S. was released in 2014 and concerns an older woman (Laura Linney) who lusts after a teenaged boy (Topher Grace). The film received a 55\% rating on Rotten Tomatoes, and many critics treated the film's premise with as much skepticism as Klause treats the premise of Venus and Adonis: 
'P.S.' contains more than its share of implausibilities and absurdities-and let's not even imagine the reception the movie would get if the genders were reversed-but if it's not Linney's finest role, it contains some of her nerviest work. (Burr, 2004)

Most of the reviews of P.S. sarcastically suggest, as this one does, that movies about older men and teenaged girls are rarely made-therefore challenging the appropriateness of a work that presents the yearning that an older woman has for a younger man. But this is simply not true. The list of present day movies that feature older male protagonists who love younger women is extensive. And there are also quite a number of very successful movies specifically about older men and teenaged girls, including Oscar award winners: American Beauty, An Education, The Big Sleep, Blame it On Rio, Circle of Two, Damage, Election, Ghost World, Girl with a Pearl Earring, Great Balls of Fire, The Horse Whisperer, Gigi, Last Tango in Paris and The Blue Angel-to name a few.

\section{Rhetoric in Venus and Adonis Early Modern vs. Modern Rhetoric}

Utilizing the approach Traub (2016) labels as 'continuity,' we can see similarities between Early Modern culture and ours. Similar to Early Moderns who were likely to have viewed the sexual situation in Venus and Adonis as 'unsettling,' we likely would view it that way, too. The only significant difference between Early Modern work on this subject and ours is in the expression; the artifice itself. P.S. is, formally, a very different work than Venus and Adonis, and not simply because (as some would assert) Shakespeare's poem is 'great art' and P.S. is not. While Venus and Adonis is an Early Modern poem and relies primarily on words to communicate, P.S. is a modern film, and as such, relies on images as well as words. Also, the language in Shakespeare's poem-which contains much dialogue between the two characters (it is in fact mostly dialogue)-is not simple; it is both bewitchingly and frustratingly complex. In contrast, the language used by the characters in P.S. for the most part resembles everyday modern speech.

\section{Ramism versus Euphuism}

Shakespeare's language, however, is not merely poetic or 'connotative,' his style was specifically chosen from among the range of approaches that typified the Early Modern period. In his doctoral thesis, contemporary theorist, Marshall McLuhan (2009) clearly delineates the two sides in what he posits as the Elizabethan 'style wars.' The two opposing camps in the debate were devotees of Cicero vs. the followers of Ramus. Ciceronians were old school stylists who thought that "the great arts are politics war and eloquence, mediocre arts are mathematics, physics, ethics, logic, grammar" (2009, p. 56). Art is "a virtue or power which enables us to act" (p. 57). McLuhan also says, "Cicero's choice and emphasis fixed the influence and oriented the interpretation of ancient thought, Greek as well as Latin, at the beginning of the middle ages and again in the Renaissance" p. 57). Cicero-like the Greek Sophists-was more concerned with persuasion than truth, and with the figures of rhetoric that served his art. Ramism (named after Petrus Ramus, a Huguenot who died in 1572) exemplified the opposite impulse. Ramists wished to strip language of unnecessary excesses and floridness in order to focus on content (i.e., it's 'truth'). McLuhan (2009) even makes the bold statement that,

The complete severance of style and matter in the Ramist rhetoric was a direct contributing influence in bringing about that deliberate impoverishment of poetic imagery 
after the Restoration. It co-operated with Cartesian innatism to render imaginative or phantasmal experience frivolous at least. (pp. 192-193)

Shakespeare's writings display a certain 'anti-Ramist' stylistic tendency. For instance, there are many similarities between Shakespeare's manner of writing and euphuism (associated with John Lyly)-a writing style very much in vogue in the 1570s. The euphuists represented the last gasp of Greek and medieval rhetoric in the Early Modern period. Critics have found stylistic references to euphuism in Shakespeare's plays, especially Love's Labour's Lost, and certain lines in Henry IV, and Romeo and Juliet. But most are reluctant to call Shakespeare a 'euphuist' because euphuism has for many years been associated with shallowness, frivolity, and effeminacy. Lately, however, literary critics like Andy Kesson have begun to assert that insisting that Shakespeare's work has no textual relationship to Lyly's work does not help us understand the Bard's poetry. He says, "in the eighteenth century Lyly is repeatedly described as an infection or disease for which Shakespeare was the cure" (2014, p. 5). Also, he observes that scholars are beginning to see that although "the denigration of Lyly's work in the eighteenth and nineteenth centuries has been an important part of the formation of the Elizabethan canon" (2014, p. 205), now, in a small step forward, Lyly is "being taught to undergraduates as an inconvenient precursor to Shakespeare" (2014, p. 204).

\section{Paradox in Shakespeare}

\section{Paradox and Euphuism}

The most obvious stylistic element that Shakespeare's work shares with euphuism is the persistent employment of paradox. Lena Ostermark-Johansen, in her essay linking the euphuistic style and nineteenth century 'effeminate' poetry, mentions Pater's language in the context of the history of paradox: "He adopted and developed a number of the rhetorical figures Lyly had introduced after such Italian models as Castiglione, who had recommended the use of antithesis as a means of obtaining stylistic grace and movement in his Cortegiano" (2002, p. 3). Croll-the first critic to attempt an in-depth analysis of Lyly in the 20th century-mentions Lyly's use of paradox, but he does not believe that antithesis is an effective lens through which to view Lyly's style because antithesis "can be both a figure of sound/words and a figure of thought. In Lyly's use, antithesis is purely a scheme, a figure of the arrangement of words for the effect of sound, it is not about revealing striking and new relations between things" (1916, p. xvii). More recently, critics have contested this notion. McLuhan, for instance, suggests that Lyly's use of paradox was not merely as embellishment, stressing that one of the features of euphuism was that "the patterning of the language is related to thought, to ideas, the formality of the language is the working out of ideas" (2009, p. 45).

\section{Paradox in Venus and Adonis}

If Shakespeare is 'working out' ideas in Venus and Adonis, what conclusions does he arrive at, and to what degree is he aided by rhetorical technique? The nature of paradox as figure is that the medium is undoubtably the 'message.' Paradox forces us to think while (paradoxically) staving off the possibility of resolution. The form is by definition binary; paradox displays an idea or image and its opposite simultaneously. But in this case, though opposites attract, they do not resolve themselves into a clear synthesis in the Hegelian manner. Nearly all of Venus's romantic feelings, 
and her advances on Adonis are expressed in the form of paradox. The fourth stanza contains no less than four paradoxes in six lines:

And yet not cloy thy lips with loathed satiety, / But rather famish them amid their plenty, / making them red and pale, with fresh variety / Ten kisses short as one, and one long as twenty / A summers day will seem an hour but short, / being wasted in such time beguiling sport." (Shakespeare, 2002, p. 176)

What ideas are suggested by the expression of these paradoxes? This passage observes that when one is satisfied, one does not wish for more kisses, but when one is famished one will consequently desire-and receives-more. Yet this paradox is unresolved, for being famished leads to plenty, and being sated leads to lack of desire. Both states have their advantages and disadvantages; how to choose? The paradox sets us thinking about the contradictions of desire, without offering a resolution. If we think of cheeks both 'red and pale,' and a plentitude of short kisses versus a single kiss that takes a long time-then a possible explanation for Shakespeare's use of paradox is clear. Sexual activities are not logical. Sex may exist in collusion with love, but also with hate, or physical violence-in the case of rape or lack of full consent. Love and sex may lead to both affection and irritation, both impatience and satiety. Shakespeare piles paradox upon paradox in the body of the poem and these contradictions succeed in accurately describing the contradictory realities of love troubled by lust.

\section{The Implications of Paradox in Venus and Adonis}

But it is at the end of the poem when Venus is rejected by her would-be lover, that she addresses not only the paradoxical nature of love and sex, but the paradoxical nature of our attitudes towards love and sex. Here Venus curses love:

Sorrow on love hereafter shall attend.

It shall be waited on with jealousy;

Find sweet beginning, but unsavoury end;

Ne'er settled equally, but high or low.

That all love's pleasure shall not match his woe.

It shall be fickle, false and full of fraud,

Bud and be blasted in a breathing-while;

The bottom poison, and the top o'erstrawed

With sweets that shall the truest sight beguile.

The strongest body shall it make most weak,

Strike the wise dumb, and teach the fool to speak.

It shall be sparing and too full of riot,

Teaching decrepit age to tread the measures.

The staring ruffian shall keep in quiet,

Pluck down the rich, enrich the poor with treasures.

It shall be raging mad, and silly mild,

Make the young old, the old be come a child...

It shall be cause of war and dire events,

And set dissension 'twixt the son and sire;

Subject and servile to all discontents,

As dry combustious matter is to fire.

Sith in his prime death doth my love destroy, 
They that love best their loves shall not enjoy. (Shakespeare, 2002, pp. 234-235)

Could there ever be a more accurate description of the paradoxes that characterized Elizabethan attitudes toward sexuality? How-in a culture where women are 'governed' by the patriarchy and yet still empower themselves to find sexual satisfaction-could love and sex cause anything but 'dissension'? And the men who loved other men 'best,' would most certainly not be permitted to 'enjoy' their loves. Those who reject the New Historicism might insist that Shakespeare's paradoxical representations of love in the curse of Venus are not merely reflections of the sexual politics of the time, but instead are the poetic embodiment of 'truth'-the essential tragic nature of love.

But the nature of Shakespeare's rhetoric suggests the opposite. Sexual activities and loving relationships were copious-many and varied-during Shakespeare's time. Marion Trousdale (1982) speaks of Shakespeare's rhetoric also being copious; and suggests that copiousness was characteristic of Ciceronian rhetoric. She also suggests this rhetoric had a tenuous relationship to didacticism. According to Erasmus, "nature rejoices in variety" (1963, p. 41) so it behooves the Early Modern rhetorician to write copiously, that is, expand, and express one idea in a variety of ways. This means that in euphuistic writing-as in the works of Shakespeare-we are often offered a list of what seems like variations on a theme; we are treated to the author saying the same thing in various ways, repeatedly. But the list occasionally becomes so extended and complex, that the original 'message' is obscured. Trousdale (1982) reminds us that Elizabethans appreciated this kind of poetry. Rather than expecting a work of art to reveal a single straightforward message, "the more successful the artistic creation the greater number of moral lessons can be taken from the tale" (p. 116), and "even a simple tale may reveal a huge number of meanings not consonant with each other", p. 118).

Unlike many other literary and dramatic works of the Medieval and Early Modern periods, Shakespeare's plays often defy thematic exegesis. It is, at any rate, a challenge to whittle any of his plays or poems down to one, cohesive, non-paradoxical moral. This is perhaps one reason why his work seems so modern today. This aspect of Shakespeare's style, along with Shakespeare's reversal of the usual romantic situation (uncharacteristic for his time) in Venus and Adonis-placing the woman in the position of relentless huntress, and the male in the position of passive object of a desiring gaze-exemplify the 'queerness' of Shakespeare's poem.

Venus and Adonis is as complex and contradictory as sex and love in Early Modern England. Trousdale (1982) tells us, for the Elizabethan rhetorician "the words that we use never exhaust all that we could say about a sensible experience" (p. 130). Was Shakespeare moved by the contradictory sexual practices and attitudes to sexuality of his time to create an accurate, but somewhat amoral, reflection of it? Or was this reflection unconscious? Perhaps Shakespeare was drawn to unresolved paradoxes and the Ciceronian rhetorical style, because this technique-by its very nature-teaches us an important-but again, somewhat paradoxical-lesson; that while life sometimes leaves us with a myriad of choices, it often leaves us with no lessons at all. 


\section{References}

Bloom, H. (1999). Shakespeare and the invention of the Human. New York, NY: Riverhead Books.

Burr, T. (2004, November 5). Lust and loss combine in 'p.s.' The Boston Globe. Retrieved From http://archive.boston.com/ae/movies/articles/2004/11/05/lust_and_loss_combine_in_ps/

Bray, S. G. (2002). Homoerotic space: The poetics of loss in renaissance literature. Toronto, ON: University of Toronto Press.

Callaghan, D. (2002). Shakespeare sithout women. Abingdon, UK: Routledge.

Erasmus, D. (1963). On copia of words and ideas. (D. King \& H. Rix, Trans.). Milwaukee, WI: Marquette University Press.

Foucault, M. (1978). The history of sexuality, vol 1: An introduction. New York, NY: Vintage.

Foucault, M. (1998). What is an author? In J. Faubion (Ed.), Ethics, aeshetics and episte mology. (pp. 205-222) New York, NY: New York Press.

Gibson, J. L. (2000). Squeaking Cleopatras. Stroud, UK: The History Press.

Greenblatt, S. (1991). Resonance and wonder. In I. Kart an. D. Lavine (Eds.), Exhibiting cultures: The poetics and politics of museum display. Washington, WA: Smithsonian Institute Press.

Kesson. A. (2014). John Lyly and Early Modern authorship. Manchester, UK: Manchester Uni versity Press.

Klause, H. (1999). Why Venus and Adonis can be redeemed. In H. Bloom (Ed.), Shake speare's sonnets and poems. (pp. 100-102) Broomail PA: Chelsea House.

Lyly, J. (1916). The anatomy of wit euphues and his England. M. Croll (Ed). London: George Routledge and Sons.

McLuhan, M. (2009). The classical trivium. Berkeley, CA: Gingko.

Orgel, S. (1989). Nobody's perfect: Or why did the English stage take boys for w women? South Atlantic Quarterly, 88, 7-30.

Østermark-Johansen, L. (2002). The death of Euphues: Euphuism and decadence in LateVictorian literature. English Literature in Transition, 1880-1920, 45(1), 4-25.

Saunders, B. (2006). Desiring Donne: Poetry, sexuality, interpretation. Cambridge, MA: Harvard University Press.

Shakespeare, W. (2002). Venus and Adonis. In C. Burrow (Ed.), William Shakespeare the complete sonnets and poems (pp. 234-235) Oxford, UK: Oxford University Press.

Sinfield, A. (2006). Shakespeare, authority, sexuality. London, UK: Routledge.

Traub, V. (2016). Thinking sex with the Early Moderns. Philadelphia, PA: University of Pennsylvania Press.

Trousdale, M. (1982). Shakespeare the rhetorician. Chapel Hill, NC: University of North Carolina Press. 2

Wells, S. (2004). Looking for sex in Shakespeare. Cambridge, UK: Cambridge University Press. 